\title{
DEVELOPING PODCAST OF ENGLISH SONG AS MEDIA FOR ELT LISTENING
}

\author{
By \\ Amirudin Latif \\ English Department of Muhammadiyah University of Metro \\ e-mail:amirpubian@gmail.com
}

Abstract:

\begin{abstract}
Listening is one of the fundamental language skills.Based on the pre survey research, many students at Senior High School were not interested in listening course. This research tried to develop podcast of English song (PES) as the media in order to help the teacher in the teaching of listening and make the students interested in listening course. The type of the reseacher is developmental research.The steps of this research are self evaluation, expert review and one-to-one, small group, and field test. The subjects of this research are the students of SMAN 03 Metro and SMK Muhammadiyah 03 Metro. The researcher collected the data by giving some questionnaires to the expert review and students to find out whether the media is applicable and suitable or not. The result showed that: first, most of the studentsfelt fun and enjoyable in the learning process of listening course. Second, PES media was applicable, the students were active, very enthusiastic, excited with PES media.
\end{abstract}

Key Words: English song, Listening media, Podcast.

Language is a power, and it is very important for human life. Language can be used to convey ideas, opinions, and feelings by oral or written ways.Actually, almost several countries use English as a second language and foreign language. Especially in Indonesia , English as a foreign language. In fact, it is learned and used in the field of education, work, sciences and technological sides. Formally, English becomes the first foreign language taught and learned at schools.

The students at schools must have English capability in four skills namely listening, speaking, reading and writing. One ofthe important skills which must be acquired is listening. People can expect to listen twice as much as someone speak, four times more than people read, and five times more than people write. It means that listening is the first process to respond, understandand remember the message. Listening is one of the fundamental skillsout of the other skills. If the students can listen well, so they can produce the language correctly and be able to speak, read,write clearly.The proficiency of understanding and using English skills; speaking, reading, and writing, basically depends on listening comprehension.Listening is the most difficult skill among the other skills.

In learning English, students are expected to get the point of spoken or written information. In fact, the real condition is not like what are expected. The students have problem in learning English especially in listening. The students did not understand what the native speakers meant. 
They lacked of producing the language, Consequently they can not speak, read, and write well. They sometimes are bored with the English lesson, especially in listening. The teachers rarely used media or developed listening media that made the students interested in joining the learning process. This condition is proven by score data of students' achievement at the tenth Grade of State Senior High School 3 Metro. the percentage of the low score achieved by the students in the test is $35 \%$ while the percentage of the high one is only $15 \%$. It proved that students' learning echievement is still low. Meanwhile in the other schools,especially in metro for example SMK Muhammadiyah 03 Metro, the listening score was low, because the teacher did not use the good media to improve the students' listening skill.

Furthermore, podcasting is unlimited resource of authentic material which can be used for teaching as well as learning foreign languages. Podcasting becomes alternative method of learning which can help to improve students listening skills. Podcasting is also a tool which allows teachers to share their ideas and suggestions in order to improve their method of teaching.

Thus, Podcast Media is important to be used in the teaching of listening,becauseit is very interesting media which can motivate the students to learn. From the problems above, the researcher wants develop podcast of English song as Listening Media.

\section{Research Questions}

Based on the background of the study mentioned above, the research questions are formulated as follows:

1. Can podcast be developed as media in the teaching of listening?

2. How can podcast be developed as media in the teaching of listening?

\section{Research Objectives}

In line with the research questions, the study is intended to:

1. Find out whether podcast can be developed as media in the teaching of listening.

2. Find out how podcast can be developed as media in the teaching of listening.

\section{Benefit of the Research}

The result of the study gives contribution in the field of English language teaching and second language acquisition. The product of the research is very beneficial for the following persons who are engaged in the field of ELT and SLA.

1. The students 
The product of the research can be used to help the students to improve their listening skill.

2. The teachers

The product of the study can be used as alternative teaching media for teachers who are lacking of creativity in developing English language teaching media.

\section{Other Researchers}

The result of the study can be a reference for other researchers who want to develop English language teaching media in their research and development.

\section{Theoretical Reviews}

Listening, according to Helgesen (2003, 24), is an active, purposeful processing of making sense of whatsomeone hear. Listening has been identified as one of the most used and one of the most important communication skills in personal, academic, and professional settings alike. To succeed in communication, listening skill is badly needed. Russel and Russel in Hasyuni $(2006,8)$ also state that listening skill is listening with comprehension, attention and appreciation. Then, listening activity needs integrating skill of language, such as pronunciation, vocabulary mastery, writing, speaking, and reading. In addition, Richards and Schmidt(2002, 313) argue that Listening skill is the process of understanding speech in a first or second language. The study of listening comprehension in second language learning focuses on the role of individual linguistic units(e.g.,phonemes, words, grammatical structures) as well as the role of the listener's expectations, the situation and context, background knowledge and topic.

To teach listening skill, a good ELT media is needed. One of the media which can be used in the teaching of listening is podcast. Braun $(2007,2)$ describes that podcasts are the regulary produced audio and video files that are available for subscription and that can be automatically downloaded to a computer or portable audio and video device. A digitalrecording of music, news or other media that can be downloaded from the internet to a portable media player. The term originated from "P.O.D.", meaning Portable On Demand, and "cast", relating to the term broadcast.Interested listeners are able to download these MP3 files onto their personal computer or personal mp3 player af any type. This file can be listened to at the convenience of the listener. Learners can listen over and over to any material that is of interest to them. 
In addition, Smaldino $(2005,7)$ states that Podcast (from the words "iPod" and "broadcasting") are recorded audio files in MP3 format that are distributed over the Internet. This audio files can be sent automatically to subscibers' convience. With podcasting sofware, studenst and teachers can creare their own showsand have download audio files and listen them on their computers or portable audio players.

Furthermore, according to Farkas $(2007,190)$ Podcast is an audio file whichcan be downloaded from the Internet, and it can be used to supplement online and face-to-face classes, allowing students to personalize their learning and freeing faculty to try more interactive teaching methods in the classroom.Podcast asaudio content is available on the internet that can be automatically delivered to our computer or MP3 player.

The kind of podcast used in this study is English song. Songs are also easily available; songs present new vocabulary and expressions in context. Through songs students become familiar with the pronunciation of native speakers, and they also provide topics for discussion.Grifee $(2001,10)$ states that song is part of music that someone sings throughwords. Today, almost all people especially students, preferlistening to songs as they can be good entertainment in boring activity. Listening to the song appreciating the lyrics, rhythms, vocal and melody and try to understand the meaning. Song is part of music which contains lyrics being sung. The song itself consists of words which express the writer's ideas, feelings, and experiences. can be used as a medium to teach vocabulary to the students and they can produce the language. Thus, songs can be developed and used to teach English vocabulary especially in the listening skill.

In conclusion, teaching listening needs a good media in order that the skill can be acquired by all of the students. In this study, podcast of English songs is developed through a research and development. The product of the study is English teaching media which can be used in the teaching of listening.

\section{Methods}

The design of the study is research and development which tries to develop podcast of English song as media in the teaching of listening at the tenth grade of senior high school. The study adapts the model of research and development proposed by Tessmer (1993:35). In this study, Podcast of English song is developed 
as media of teaching listening through several steps namely self evaluation, expert reviews, one to one, small group, and field test.

In the step of self evaluation, the researcher evaluates the existing English teaching media which is ordinary used in the teaching of listening. Then the researcher observes the implementation of the existing media to find the strength and the weaknesses of the media which can be used as a basis of the media development in this study. Next, considering the strength and the weaknesses of the previous media, podcast of English song is developed as the media of teaching listening at the tenth grade of senior high school.

In step of expert reviews, the researcher submits podcast of English song which has been developed for a media of teaching listening to two experts namely Drs. Bambang Eko Siagianto, M.Pd and Dedi Turmudi, M.A TESOL. The two experts are asked to give suggestion and comments to the podcast of English songs which has been developed as media of teaching listening.

In the step of one to one, the researcher uses two schools namely SMA N 3 Metro and SMK Muhammadiyah 3 Metro. The researcher utilizes two students as informants who are asked to give the suggestion about PES media.Thus, total of the students in this step are four students of each the schools as informants who give the comment about the media. The result is used to revise the product.

In the step of small group, the researcher takes six students in two schools namely SMA N 3 Metro and SMK Muhammadiyah 3 Metro. Thus, total of the students in this step are twelve students. Every students are dividedintotwo small groups, and the small groups consist of three students of each school. The studentsassemble an PES media, then complete and give suggestion in questionnaire form about PES media which has been revised based on expert review and one-to-one.

In the step of field test, the researcher wants to testthe product which has been developed. Purposing to produce a media facilitating the studentswith the easier learning proces of listening, learning more vocabulary, and learning how to pronounce the English language. The researcher distributesthe questionnairecontaining the items of applicability, readability, and audibility of podcast of English song to the students. The researchertakesthe tenth grade of SMA N 3 Metro and Tenth grade of 
SMK Muhammadiyah 3 Metro as respondents with the total number 24 students from SMA N 3 Metro and22 students fromSMK Muhammadiyah 3 Metro. The result of this step become the final product namely podcast of English songs which is used as media in the teaching of listening.

\section{Results and Discussion}

\section{Result of the First Product Testing}

Podcast Of English Song (PES) is development of a learning media especially in listening. Itis used in English learning to attract the students'motivation in listening skill at the tenth grade of seniorhigh school. The PES media is applied for listening process. The PES media consistsof four levels namely beginner, medium, advanced, and superstar. Therefore, the students are interested in listening.

The first product designing of the PES mediafor listening skill was reviewed by expert review and one to one. The steps were done after the researcher got self evaluation of the students. There weretwo expert reviewers. They gave some suggestions and filled some questions ona questionnaire about development of the media. Theywere the validators for the PESmedia. The expert revieweranalyzed the questionnaire. The result of the questionnaire is valid. But, the expert reviewer suggestedthe researcher to add one level in field test and each levels consist of ten songs. After that the researcher continued to the next step.

Based on the suggestions of the expert reviewer, the researchers revised the PES media by adding one level and songs. Then, the researcher continued to the next step. The next step was One to One. It was to review the first prototype of the PES media. The one to one step consists of two students. They were from SMA N 3 Metro and SMK Muhammadiyah 3 Metro. Thus, the total of the respondents was four students. The students were asked to used the PES media.After that,theyfilled some questions and gave some suggestions on the questionnaire. Based ontheir suggestions, it can be concludedthat thePES media is creative, interesting and enjoying.

\section{Result of the First Product Testing}

The result of the first product testing is called small group. The researcher took two schools to test the product namely SMA N 3 Metro and SMK Muhammadiyah 3 Metro. There were six students as respondents for both of the schools in the 
small group. The respondents were asked to use the PES media. Then, they filled some questionnaires and gave some suggestions.

Based on the result of the applicability, readability and audibility in SMA N 3 Based on the result the questionnaire containing three points namely applicability, readability and audibilityof PES media per item above, it can be concluded that item number seven and eight get the lower score than others. Therefore it was revised by researcher.

Based on the result of the questionnaire containing three points namely applicability, readability and audibility of PES media In SMK Muhammadiyah 3 Metro, it can be concluded that the item number seven (the sound audible) get lower score than others. Therefore it was revised by researcher.

\section{Revision of the First Product}

The researcher added answer key in PES media, and made the layout colorful, and the researcher edited PES media till the sound was audible clearly. After the researcher finished the PES media, the researcher continued to the next step.

\section{Result of the Second Product Testing}

The result of the second product testing is called field test. There were twenty two students at the tenth grade of SMAN 3 Metro and SMK. Muhammadiyah 3 Metro. The researcher conducted the field test after getting feedback from the small group and doing the revision.

Based on the result applicability, readability and audibility in the field test of SMA N 3 Metro and SMK Muhammadiyah 3 Metro, the result gets high score.

It can be concluded that the scores in the field test increase from the scores in the small group. It means that the the students can understand the questionnaire, and they can use the PES media for listening.

\section{Revision of the Second Product}

Based on the result of testing product PES media for listening skill, the researcher revised the product which concern in all of aspect item numbers that have low score.

The result shows that all of item numbers have high score and almostof the students did notfind the difficulties to use the media. The researcher made the sound clear by using good speaker, and added the colorful wallpaper in PES media . Therefore, based on the revision, the students can be more interested, and understand in using the media for listening process.

\section{Refinement of the Second Product}


The PES media for listening media has not too much revisions. The revisions are addition of user manual, added answer key , and made the sound clearly . They are obtainedfrom the questionnaires of the expert review and the students. The result of the field test of the PES media is high.

\section{Discussion of the Final Product}

Based on the tests and revision of the PES media given at the tenth grades of SMA N 3 Metro and SMK Muhammadiyah 3 Metro, the PES media is extraordinary media whichis ever used in listening skill. Then, the PES media have the complete levels and have great challenges in each levels that appropriate with students' skill. Therefore the PES media for listening skill can be used for the students and the teacher.

The researchers got good respondents from the students of SMA N 3 Metro and SMK Muhammadiyah 3 Metro. The PES media helped the students in listening process by using many song in each levels.

\section{Conclusion and Suggestions}

\section{Conclusion}

Referring to the findings of this research, the researcher revised the learning media as follows.

1. The PES media for listening is application for listening that not only hearing the sound but has menu display. Thus. The PES media made the students attracted and useful for them. The media can helpthe teachers teach in the listening class and drill the students' listening skill. Therefore, the students can understad and memorize many vocabularies from PES media .

2. The PES media makes the students happy, enjoyable, enthusiastic, and attracted in listening and the PES media can be applied at the Senior High School.

3. The PES media is developed by researcher with four levels and have different songs and instruction in each levels. Therefore, the PES media makes the students are not boredwith listening process. In addition, this media is very challenging the students to triy all of the levels in PES. It is developed by researcher with user manual. Therefore, the students and the teachers are easy in using the PES media in the class.

\section{Suggestions}

This research attempts develop Podcast of English Song as listening media. 
It is an English learning media for listening using a song. Referring to the findings of this research, the researcher gives some suggestions for those who keep in touch English language teaching and learning.

1. The teachersare suggested to use Podcast of English Song as listening media at the tenth grade of Senior High in order that the students can be happy, enjoyable, enthusiastic, and interested in their learning.

2. The next researchers are also suggested to use Podcast of English Song as listening media to make the students interested in learning the skill. The media can be used to teach other English skill beside listening such as speaking, reading, and

\section{References}

Braun,L.W.(2007).Listen up!: podcasting for schools and libraries. Medford:InformationToday.
Farkas, M. G. (2007). Social Software in Libraries: Building Collaboration,Communication and Community Online. Medford, NJ: Information Today.

Griffee, D.T. (2001). Songs in Action. Hertfordshire: Prentice Hall International.

Hasyuni . (2006). The Students' Preferred Activities for English Listening Classes (A Survey Conducted to the Second and Fourth Semester Students of English Department of FKIP.

Helgesen, M. (2003). Teaching listening. In D. Nunan (Ed.) Practical English Language Teaching. New York: McGraw-Hill.

Richards, J. C., \& Schmidt, R. (2002). Longman dictionary of language teaching and applied linguistics. Third Edition. London: Longman (Pearson Education).

Smaldino, S. E., Russell, J. D.. \& Lowther, D. L.(2007). Instructional Technology and Media for Learning (9th ed.). Upper Saddle River, NJ: Prentice Hall.

Tessmer in Wamala. (2014). Developing Evaluation for Speaking Skill based on Content based Instruction Approach at Student of SMA N 1 Sekampung. Kota Metro: UM Metro 